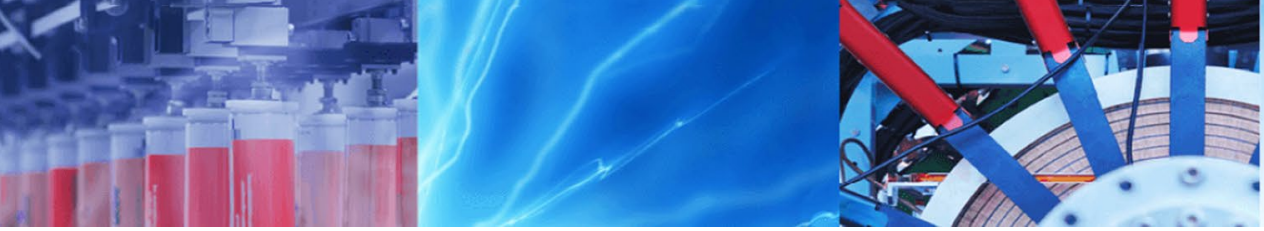

Research Article

\title{
The impact of heavy metals in water from abandoned mine on human health
}

\author{
Eva Singovszka ${ }^{1} \cdot$ Magdalena Balintova $^{1} \cdot$ Natalia Junakova ${ }^{1}$
}

Received: 18 December 2019 / Accepted: 8 April 2020 / Published online: 20 April 2020

(c) Springer Nature Switzerland AG 2020

\begin{abstract}
The present study was conducted to investigate the heavy metal ( $\mathrm{Mn}, \mathrm{Cu}, \mathrm{Zn}, \mathrm{As}$, and $\mathrm{Cd}$ ) concentration of surface water in Smolnik creek in Slovakia. Furthermore, the study was aimed to determine the potential environmental health risk that the heavy metal concentration poses to the public. The values of the ecological potential index for the water in the study area were more than 600 , reflecting a very high risk from the water body posed by these metals. Thus, this was also the reason to examine the impact of these heavy metals on the health of the population. Based on the heavy metal concentration, health risk assessments such as the chronic daily intake and hazard quotient (HQ) were calculated. Results showed that the daily intake of the heavy metals from all five samples taken from Smolnik creek was lower among adults than among children for two pathways of exposure. The non-carcinogenic hazard quotients of heavy metals in the studied area were higher among adults than among children. At all five sites, the $\mathrm{HQ}$ values for dermal exposure for adults were higher than 1. The HQ values for exposure through ingestion for adults and children were higher than 10 for almost all sites, indicating a disaster situation.
\end{abstract}

Keywords Heavy metals $\cdot$ Acid mine drainage $\cdot$ Human health $\cdot$ Health risk assessment

\section{Introduction}

Heavy metals, as specific non-biodegradable contaminants, accumulate in living organisms, and at low levels of concentration, they already cause various serious diseases and disorders. Moreover, they can enter into surface and groundwater and thereby contaminate and contribute to deterioration of the quality of drinking water and water used for irrigation $[2,16,27]$. The biggest portion of heavy metals settles in river and reservoir sediment [3, 31, 32].

In recent years, environmental scientists have been focused on the examination of water pollution from heavy metals $[9,21,31]$. Heavy metals can cause great environmental damage if they occur under certain conditions allowing them to accumulate to a toxic level [24].
Some metals $(\mathrm{Cu}, \mathrm{Zn})$ are essential for proper body growth and support in living organisms, but these elements become toxic at high concentrations. However, other metals ( $\mathrm{Cd}, \mathrm{Mn}, \mathrm{As}$ ) are very toxic and dangerous to human life. Zinc, for example, causes sideroblastic anaemia [24]. At very low concentrations, cadmium is a very strong toxin whose accumulation in tissues can cause infertility, organ dysfunction, damage, and cell death. The occurrence of arsenic in its organic form is less harmful to health, but in the form of inorganic compounds, especially in water, is very toxic [25]. If manganese occurs in higher concentration in surface water, it can lead to mental illness, including Alzheimer's disease and manganism [39].

Many methods and methodologies (geoaccumulation index, pollution load index, etc.) have been developed

Eva Singovszka, eva.singovszka@tuke.sk; Magdalena Balintova, magdalena.balintova@tuke.sk; Natalia Junakova, natalia.junakova@ tuke.sk $\left.\right|^{1}$ Institute of Environmental Engineering, Faculty of Civil Engineering, Technical University of Kosice, Vysokoskolska 4, 04200 Kosice, Slovakia. 
for assessing the environmental risks of heavy metals [29, 30, 33-36]. In fact, usually, many types of heavy metals accumulate simultaneously and cause combined contamination. For this reason, Hakanson [13] has developed a potential environmental risk index that has introduced a toxic response factor for the substance and can therefore be used to assess the combined risk of pollution to the ecological system.

The novelty of this manuscript is the study of health risks caused by contamination of surface waters with heavy metals, the source of which is acid mine waters, because there is currently insufficient attention devoted to this issue. Acid mine drainage (AMD) is a global environmental problem, despite extensive research on predictive and preventive methods [7]. Sulphide wastes act through atmospheric and aqueous oxidation, causing acidic waters with high contents of sulphate, iron, and potential toxic metals $[4,8,18,28]$. Acidic waters which originate from pyritic waste or ore may also be anomalously rich in trace elements such as $\mathrm{Ni}, \mathrm{Co}$, and $\mathrm{Sb}[5,17]$.

In the Slovak Republic, there are some locations with AMD production. The Smolnik creek is contaminated by AMD with a high metal concentration and a low $\mathrm{pH}$ (approximately 3-4) due to chemical oxidation of sulphides and other chemical processes [19]. The impact assessment of heavy metals on the environment and on human health was the reason for regular monitoring of the quality of surface water and sediments, as well as of the geochemical development in the run-off of the Pech shaft and the whole Smolnik creek, which are affected by acidic mining waters. The assessment of the potential environmental risk is mentioned in [30].

The aim of this study is assessing the associated level of risk for adults and children through ingestion and dermal contact in Smolnik waters.

\section{Materials and methods}

\subsection{Description of the study area}

The abandoned Smolnik ore deposit is situated in the Slovak Ore Mountains (Slovenske rudohorie-in Slovak) in the south-east of Slovakia. The Smolnik deposit is the best-known volcano-sedimentary ore complex in which pyrite and chalcopyrite are dominant ore minerals. After the stoppage of the mining activity in 1990, the mine was flooded and more than 6 million tons of pyrite ore of various qualities has been abandoned in this mine. An ecological collapse occurred in 1994, which caused a negative influence on the environment. Surface water and sediment in Smolnik creek were contaminated by AMD seeping from an abandoned mine.
At present, AMD still contaminates surrounding area. The Pech shaft receives the majority of water drainage from the flooded Smolnik mine area and discharges it in the form of acid mine drainage (pH 3-4, Cu 3-1 mg/l; Zn 13-8 mg/l, Mn 32-19 mg/l, and As 54-18 $\mu \mathrm{g} / \mathrm{l})$. Increases in $\mathrm{pH}$ due to AMD mixing with surface water are followed by metal precipitation and sedimentation in the aquatic environment [31, 32].

\subsection{Water sample collection and chemical characterization}

Water samples were collected from the Smolnik creek, contaminated by acid mine water from the Pech shaft, during the years 2006-2017 [6]. The sampling sites for the monitoring of water quality in the Smolnik creek (Fig. 1) were divided into: (a) reference sites without contamination by acid mine water from the Pech shaft (W1, outside Smolnik village [48 $43^{\circ} 27.6965658^{\prime \prime} \mathrm{N}, 20^{\circ} 42^{\prime}$ 59.2164803" E];W2, (b) small bridge crossing to the Pech

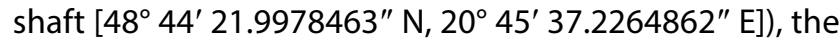
AMD from Pech shaft (Smolnik mine) numbered as W3 (source of AMD pollution [48 44' $18.0496747^{\prime \prime} \mathrm{N}, 20^{\circ} 45^{\prime}$ 44.9512482" E]), and c) two localities located under the shaft (W4, $200 \mathrm{~m}$ the Pech shaft [48 $44^{\prime} 46.1817014^{\prime \prime} \mathrm{N}$, $\left.20^{\circ} 46^{\prime} 28.4995937^{\prime \prime} \mathrm{E}\right] ; \mathrm{W} 5$, at the inflow to the Hnilec River [ $48^{\circ} 45^{\prime} 02.2642765^{\prime \prime} \mathrm{N}, 20^{\circ} 46^{\prime} 39.4108200^{\prime \prime}$ E]). Samples were collected once per year, with triplicate sampling from each sample site. Samples were collected according to ISO 5667-6-2005 Water quality-Sampling_Part 6: Guidance on sampling of rivers and streams. This standard outlines the principles and design of sampling programmes and manipulation, as well as the preservation of samples. Each sample was collected in a 0.5 -L clean and sterile polyethylene bottle that was numbered and labelled with a different site code. Directly on place, measurements of individual physico-chemical parameters were taken: air temperature, water temperature, $\mathrm{pH}$, dissolved oxygen content and conductivity. To determine the $\mathrm{pH}$ of water samples, a multifunction device MX 300 X-mate Pro (Mettler Toledo) was used. The samples were taken to the accredited laboratory as soon as possible, for the chemical analysis of water samples was used ICP-AAS method.

\subsection{Assessment of human exposure to heavy metals in water}

The assessment of human health risks, specifically for children and adults, due to acid mine drainage exposure through contaminated soil and water was conducted in accordance with the [38], Guidelines for Risk Assessment for Volume I of the Superfund part of the Human Assessment Manual (Part A) and methodical guideline 1/2012 


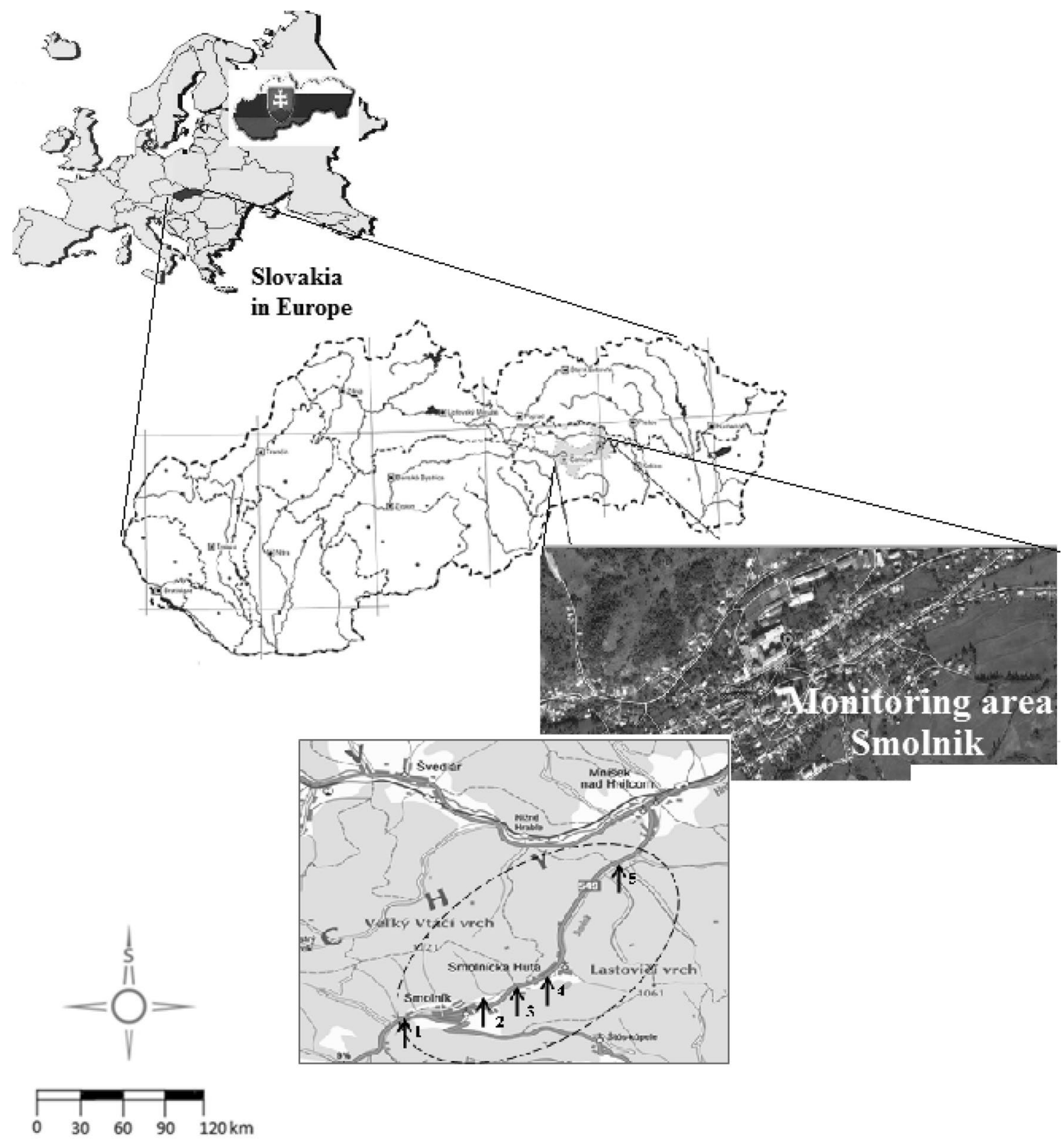

Fig. 1 Study area and locations of water sampling

(risk assessment legislation in the Slovak Republic). The assessment was divided into two routes of human exposure, ingestion and dermal exposure, respectively. The chemical daily intake (CDI) of each heavy metal via each pathway was calculated as shown in Eq. (1) (dermal pathway) and Eq. (2) (ingestion path). The dermal exposure pathway is the sum of the paths of overexposure of various parts of the body (heads, arms, hands, feet, and legs). The results from CDI by both pathways of exposure were then compared with the documented reference dose (RfD) of each analysed heavy metal, as specified in the toxicant profiles in the Toxic Substances and Toxicity Registry [38].
$\mathrm{CDI}_{\mathrm{dermal}}=\frac{\mathrm{CW} \cdot \mathrm{CF} \cdot \mathrm{SA} \cdot K_{\mathrm{p}} \cdot \mathrm{ET} \cdot \mathrm{EF} \cdot \mathrm{D}}{\mathrm{BW} \cdot \mathrm{AT}}$

where $\mathrm{CW}$ is the concentration of heavy metal, $\mathrm{CF}$ conversion factor $\left(0.001 \mathrm{l} / \mathrm{cm}^{-3}\right)$, SA the area of exposed body surface (18 $000 \mathrm{~cm}^{-2}$ adult, $6600 \mathrm{~cm}^{-2}$ child), $K_{\mathrm{p}}$ coefficient of body permeability $\left(0.001 \mathrm{~cm} \mathrm{~h}^{-1}\right)$, ET exposure time $\left(2 \mathrm{~h} \mathrm{day}^{-1}\right)$, EF exposure frequency ( 45 day year $\left.{ }^{-1}\right)$, ED duration of exposure (70 years), BW average body weight (70 kg adult, $15 \mathrm{~kg}$ child), and AT the period during which the concentration is considered to be constant $\left(25,550\right.$ day years $\left.^{-1}\right)$. 
$\mathrm{CDI}_{\text {ingestion }}=\frac{\mathrm{CW} \cdot \mathrm{IR} \cdot \mathrm{EF} \cdot \mathrm{ED}}{\mathrm{BW} \cdot \mathrm{AT}}$

where CW is the concentration of heavy metal, IR the amount of water received ( 2 I day ${ }^{-1}$ adult, $1 \mid$ day $^{-1}$ child), EF exposure time (350 day year $\left.{ }^{-1}\right), E D$ duration of exposure (70 years), BW average body weight (70 kg adult, $15 \mathrm{~kg}$ child), and AT the period during which the concentration is considered to be constant $\left(25,550\right.$ day years $\left.{ }^{-1}\right)$.

Both pathways were calculated for non-carcinogenic and carcinogenic effects. Non-carcinogenic risk is estimated by comparing the calculated CDI reference values (RfD-from database). Quantitative expression is the dimensionless quotient of danger, HQ (hazard quotient). The following applies:

$\mathrm{HQ}=\frac{\mathrm{CDI}}{\mathrm{RfD}}$

$\mathrm{HQ}$ solution: $\mathrm{HQ}<1 \Rightarrow$ no risk, $\mathrm{HQ}>1 \Rightarrow$ potential risk, $\mathrm{HQ}>10 \Rightarrow$ disaster situation.

According to alternative approaches to evaluation of the dose relationship, the answer can be selected, yielding another tangible approach to risk characterization. The quantitative expression of carcinogenic risk (CR) effects evaluates the lifetime increase in the likelihood of a number of tumour diseases above the general average in an individual population.

$\mathrm{CR}=\mathrm{SF} \cdot \mathrm{CDI}$

where $\mathrm{SF}$ is the oral slope factor in $(\mathrm{mg} / \mathrm{kg} \text { day })^{-1}$ and the $\mathrm{SF}$ is determined only for arsenic.

$C R>10^{-4}$ indicates that the socially acceptable likelihood of cancer has been exceeded for an individual, and it is likely that more than one person in 10000 people has a cancer tumour disease.

$C R>10^{-6}$ indicates that the socially acceptable likelihood of cancer has been exceeded for an individual, and it is likely that more than one person in 1 million people has a cancer tumour disease.

The hazard quotient values were used to indicate the chronic hazard index (CHI) according to [38] and Guideline
1/2012 expressed in Eq. 5. CHI values higher than 1 indicate a possibility of the occurrence of non-carcinogenic effects in individuals $[23,26]$.

$\mathrm{CHI}=\mathrm{HQ}_{\text {dermal }}+\mathrm{HQ}_{\text {ingestion }}$

\section{Results and discussion}

Table 1 shows the average values of metal contents in surface water from Smolnik creek in the years 2006-2017.

Chemical analysis results (Table 1) have shown that the concentration of hazardous substances in water exceeds the limit values according to the Government Regulation No. 269/2010 (Slovak legislation). Therefore, the aim was to analyse the impact on human health by the dermal and ingestion path of exposure.

The results of the risk assessment based on exposure to heavy metals in Smolnik creek for adults and children are presented in Table 2. Figures 2 and 3 show the hazard quotient for both pathways of exposure. Figure 4 shows the total chronic hazard index for each metal at the five study sample sites.

The daily results of rates used in the research and the daily results of the heavy metals at all measured sample sites were lower among adults than among children for dermal pathway exposure presented in Table 2 . The daily intake of heavy metals from all samples was lower in children than in adults through both routes of exposure. The release of heavy metals into the air is negligible because in this case the inhalation exposure pathway is insignificant.

The highest daily intake through the dermal exposure pathway was measured for $\mathrm{Cu}$ at site $\mathrm{W} 3$ for children (0.0146) and for $\mathrm{Zn}$ at site W3 for adults (0.027), and the lowest was measured for $\mathrm{Mn}$ at site $\mathrm{W} 1$ (adults $4.263 .9 \times 10^{-8}$, children $1.13 \times 10^{-7}$ ). The daily intake via the consumption exposure pathway was also measured for Zn at site W3 (adults 253, children 591). The lowest value for this exposure pathway was measured at site W4 for As $\left(1.53 .1 \times 10^{-5}\right)$ for children at site W1 for $\mathrm{Mn}\left(1.00 \times 10^{-3}\right)$.

Table 1 Heavy metals analysis of water regarding the metal contents from Smolnik creek

\begin{tabular}{|c|c|c|c|c|c|c|c|}
\hline \multirow[t]{2}{*}{ Media } & \multirow[t]{2}{*}{ Metals } & \multicolumn{5}{|l|}{ Stations } & \multirow[t]{2}{*}{ Limits } \\
\hline & & W1 & W2 & W3 & W4 & W5 & \\
\hline \multirow[t]{5}{*}{ Surface water $\left(\mu \mathrm{g} \mathrm{L}^{-1}\right)$} & $\mathrm{Mn}$ & $11.33 \pm 4.34$ & $108.26 \pm 108.11$ & $24833.33 \pm 6229.89$ & $1123 \pm 722.37$ & $880.42 \pm 605.94$ & 0.3 \\
\hline & $\mathrm{Cu}$ & $4 \pm 4.16$ & $12 \pm 8.46$ & $1452.43 \pm 731.72$ & $89.667 \pm 0.13$ & $39.83 \pm 31.77$ & 20 \\
\hline & $\mathrm{Zn}$ & $4.33 \pm 1.30$ & $38.25 \pm 37.61$ & $7067.25 \pm 2238.59$ & $333.5 \pm 244.29$ & $243.42 \pm 207.14$ & 100 \\
\hline & As & $1.66 \pm 1.24$ & $1.35 \pm 0.88$ & $39.84 \pm 18.99$ & $1.5 \pm 1$ & $1.13 \pm 0.61$ & 30 \\
\hline & $\mathrm{Cd}$ & $0.27 \pm 0.08$ & $0.43 \pm 0.49$ & $11.75 \pm 7.93$ & $0.825 \pm 0,64$ & $0.53 \pm 0.52$ & 5 \\
\hline
\end{tabular}

The bold values exceed the limit value (by Slovak legislation) 
Table 2 Chemical daily intake (average) of heavy metals by adults and children

\begin{tabular}{|c|c|c|c|c|c|}
\hline \multirow[t]{3}{*}{ Heavy metal } & \multirow[t]{3}{*}{ Site } & \multicolumn{4}{|c|}{ Daily intake } \\
\hline & & \multicolumn{2}{|l|}{ Dermal } & \multicolumn{2}{|l|}{ Ingestion } \\
\hline & & Adult & Child & Adult & Child \\
\hline \multirow[t]{5}{*}{$\mathrm{Mn}$} & 1 & $4.26 \mathrm{E}-08$ & $1.13 \mathrm{E}-07$ & $4.29 \mathrm{E}-04$ & $1.00 \mathrm{E}-03$ \\
\hline & 2 & $4.08 \mathrm{E}-07$ & $1.09 \mathrm{E}-06$ & $5.93 \mathrm{E}-03$ & $1.38 \mathrm{E}-02$ \\
\hline & 3 & $9.36 \mathrm{E}-05$ & $2.49 \mathrm{E}-04$ & $2.39 \mathrm{E}+00$ & $5.57 \mathrm{E}+00$ \\
\hline & 4 & $4.23 \mathrm{E}-06$ & $1.13 \mathrm{E}-05$ & $5.05 \mathrm{E}-02$ & $1.18 \mathrm{E}-01$ \\
\hline & 5 & $3.32 \mathrm{E}-06$ & $8.83 \mathrm{E}-06$ & 4.07E-02 & $9.50 \mathrm{E}-02$ \\
\hline \multirow[t]{5}{*}{$\mathrm{Cu}$} & 1 & $1.51 \mathrm{E}-05$ & $1.84 \mathrm{E}-06$ & $2.24 \mathrm{E}-01$ & $5.22 \mathrm{E}-01$ \\
\hline & 2 & $4.52 \mathrm{E}-05$ & $1.20 \mathrm{E}-04$ & $5.61 \mathrm{E}-01$ & $1.31 \mathrm{E}+00$ \\
\hline & 3 & $5.47 \mathrm{E}-03$ & $1.46 \mathrm{E}-02$ & $5.90 \mathrm{E}+01$ & $1.38 \mathrm{E}+02$ \\
\hline & 4 & $3.38 \mathrm{E}-04$ & $8.99 \mathrm{E}-04$ & $2.46 \mathrm{E}+00$ & $5.74 \mathrm{E}+00$ \\
\hline & 5 & $1.50 \mathrm{E}-04$ & $3.99 \mathrm{E}-04$ & $1.96 \mathrm{E}+00$ & $4.58 \mathrm{E}+00$ \\
\hline \multirow[t]{5}{*}{$\mathrm{Zn}$} & 1 & $1.63 \mathrm{E}-05$ & $5.58 \mathrm{E}-06$ & $1.54 \mathrm{E}-01$ & $3.60 \mathrm{E}-01$ \\
\hline & 2 & $1.44 \mathrm{E}-04$ & $3.84 \mathrm{E}-04$ & $2.08 \mathrm{E}+00$ & $4.85 \mathrm{E}+00$ \\
\hline & 3 & $2.66 \mathrm{E}-02$ & 7.09E-02 & $2.53 \mathrm{E}+02$ & $5.91 \mathrm{E}+02$ \\
\hline & 4 & $1.26 \mathrm{E}-03$ & $3.34 \mathrm{E}-03$ & $1.58 \mathrm{E}+01$ & $3.69 \mathrm{E}+01$ \\
\hline & 5 & $9.17 \mathrm{E}-04$ & $2.44 \mathrm{E}-03$ & $1.23 \mathrm{E}+01$ & 6.17E+00 \\
\hline \multirow[t]{5}{*}{ As } & 1 & $6.25 \mathrm{E}-06$ & $5.58 \mathrm{E}-06$ & $1.66 \mathrm{E}-05$ & $1.85 \mathrm{E}-01$ \\
\hline & 2 & $5.09 \mathrm{E}-06$ & $3.84 \mathrm{E}-04$ & $1.35 \mathrm{E}-05$ & $1.43 \mathrm{E}-01$ \\
\hline & 3 & $1.50 \mathrm{E}-04$ & $7.09 \mathrm{E}-02$ & 4.00 E-04 & $8.06 \mathrm{E}-01$ \\
\hline & 4 & $5.65 E-06$ & $3.34 \mathrm{E}-03$ & $1.50 \mathrm{E}-05$ & $1.60 \mathrm{E}-01$ \\
\hline & 5 & $4.24 \mathrm{E}-06$ & $2.44 \mathrm{E}-03$ & $1.13 \mathrm{E}-05$ & $1.11 \mathrm{E}-01$ \\
\hline \multirow[t]{5}{*}{$\mathrm{Cd}$} & 1 & $1.01 \mathrm{E}-06$ & $2.68 \mathrm{E}-06$ & $9.59 \mathrm{E}-03$ & $2.24 \mathrm{E}-02$ \\
\hline & 2 & $1.63 \mathrm{E}-06$ & $4.34 \mathrm{E}-06$ & $2.52 \mathrm{E}-02$ & $5.88 \mathrm{E}-02$ \\
\hline & 3 & $4.43 \mathrm{E}-05$ & $1.18 \mathrm{E}-04$ & $5.39 \mathrm{E}-01$ & $1.26 \mathrm{E}+0 \mathrm{C}$ \\
\hline & 4 & $3.11 \mathrm{E}-06$ & $8.27 \mathrm{E}-06$ & $4.01 \mathrm{E}-02$ & $9.37 \mathrm{E}-02$ \\
\hline & 5 & $2.01 \mathrm{E}-06$ & $5.34 \mathrm{E}-06$ & $2.88 \mathrm{E}-02$ & $6.71 \mathrm{E}-02$ \\
\hline
\end{tabular}

The non-carcinogenic hazard quotients of heavy metals at the sites were higher among children than among adults. The HQ values for dermal exposure for adults were $<1$ at all five measured sites. The HQ value for children was $>1$ for As at site W3, as well.

The values of the hazard quotients for exposure through ingestion for adults and children were $>10$ for almost all sites, which indicates a disaster situation. The highest value was for As at site W3 for children and adults. The lowest value was for $\mathrm{Mn}$ at site 1 for both groups. Significant exposure risks exist at sites $\mathrm{W} 1, \mathrm{~W} 2, \mathrm{~W} 4$, and W5, where the values of the chronic hazard index for $\mathrm{Cu}$, As, $\mathrm{Mn}$, and $\mathrm{Cd}$ for adults and children were $>1$; at least one value was exceeded. For site W3, all values have been exceeded $(>10)[14,20]$

Non-carcinogenic risks associated with the exposure of humans to heavy metals in water existed at the sites in the order of $\mathrm{W} 3>\mathrm{W} 1>\mathrm{W} 4>\mathrm{W} 2>\mathrm{W} 5$. The results obtained in this study have shown a more serious risk of exposure to heavy metals at sample site $\mathrm{W} 4$ relative to the other four sample sites.

Specific carcinogenic risk evaluation of the various samples indicates that the carcinogenic risk from arsenic varies among the sites (Fig. 5). Compared to other sites, the arsenic at site W3 yielded the highest results for cancer risk by dermal exposure. The arsenic cancer risk values were 2.42 $\left(C R_{\text {dermal }}\right.$ adult) and $1.2\left(C R_{\text {dermal }}\right.$ child). There was a significant cancer risk from arsenic by ingestion exposure at site W5, where the arsenic cancer risk values were $0.07\left(C_{\text {ing }}\right.$ adult) and $0.17\left(\mathrm{CR}_{\text {ing }}\right.$ child). The total cancer risk of arsenic is shown in Fig. 2. The values of cancer risks of arsenic at all five measured sites were higher than $1 \times 10^{-4}$, which is

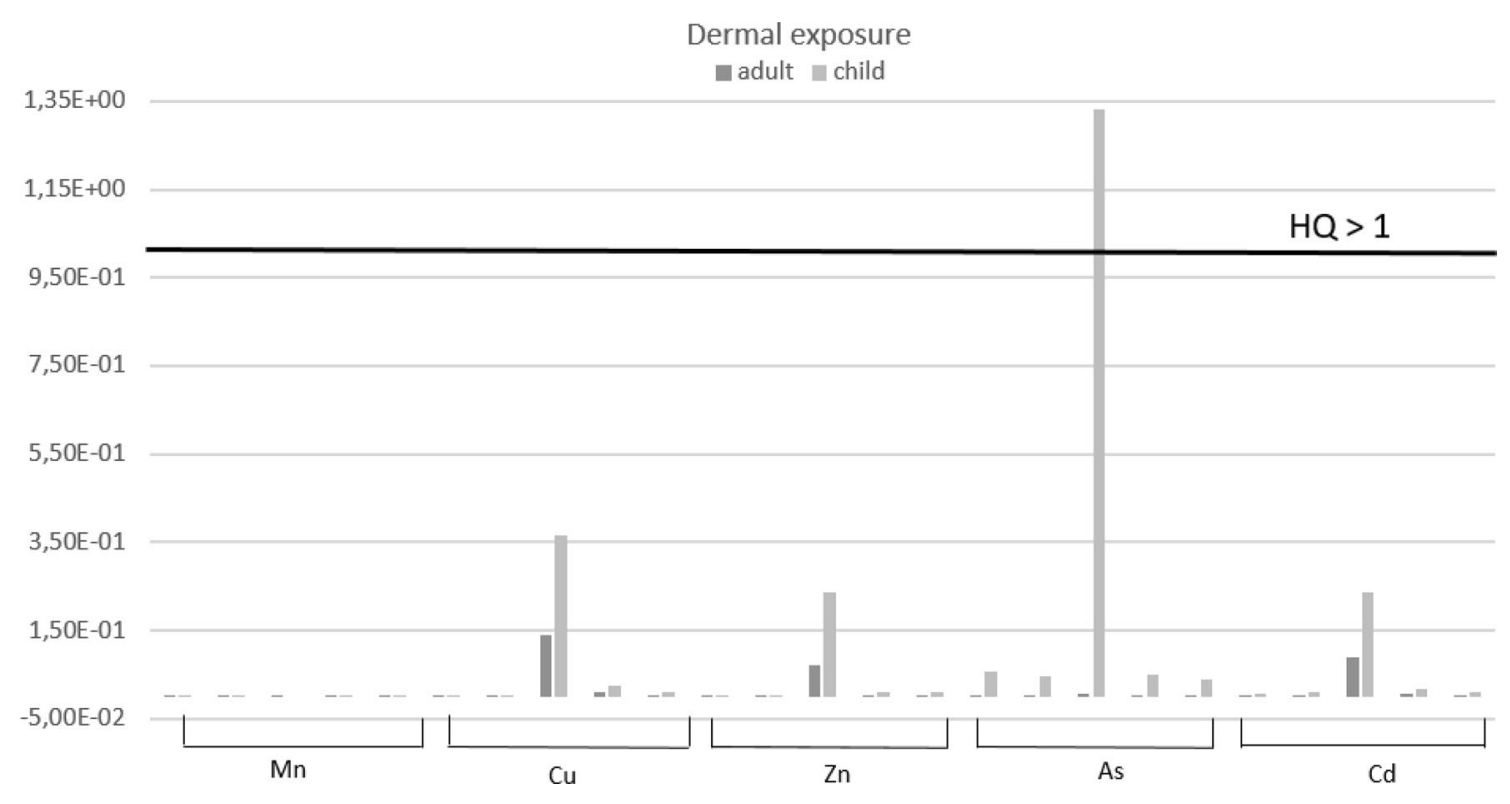

Fig. 2 Hazard quotient for dermal exposure 


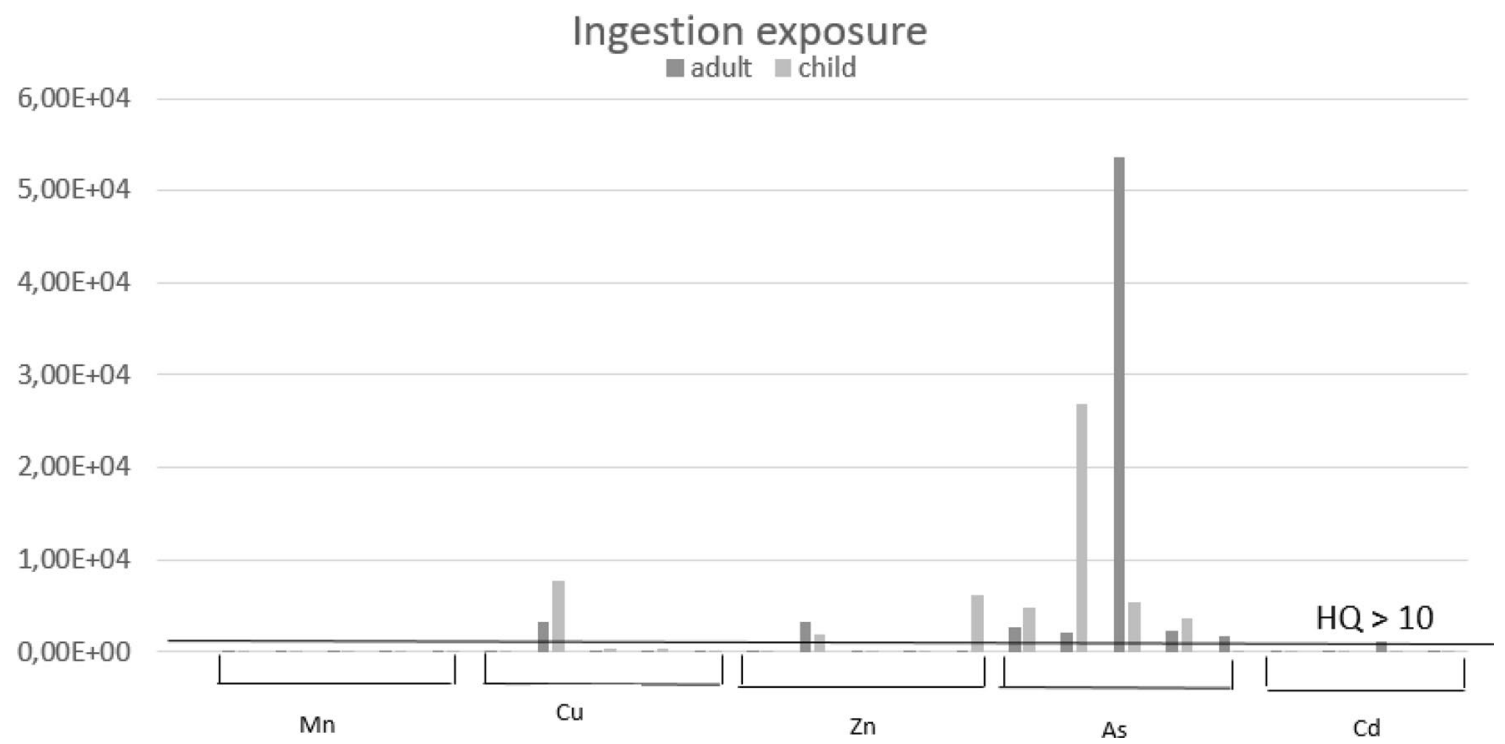

Fig. 3 Hazard quotient for ingestion exposure

Fig. 4 Total chronic hazard index for each metal at the five study sample sites

\section{Total chronic index}

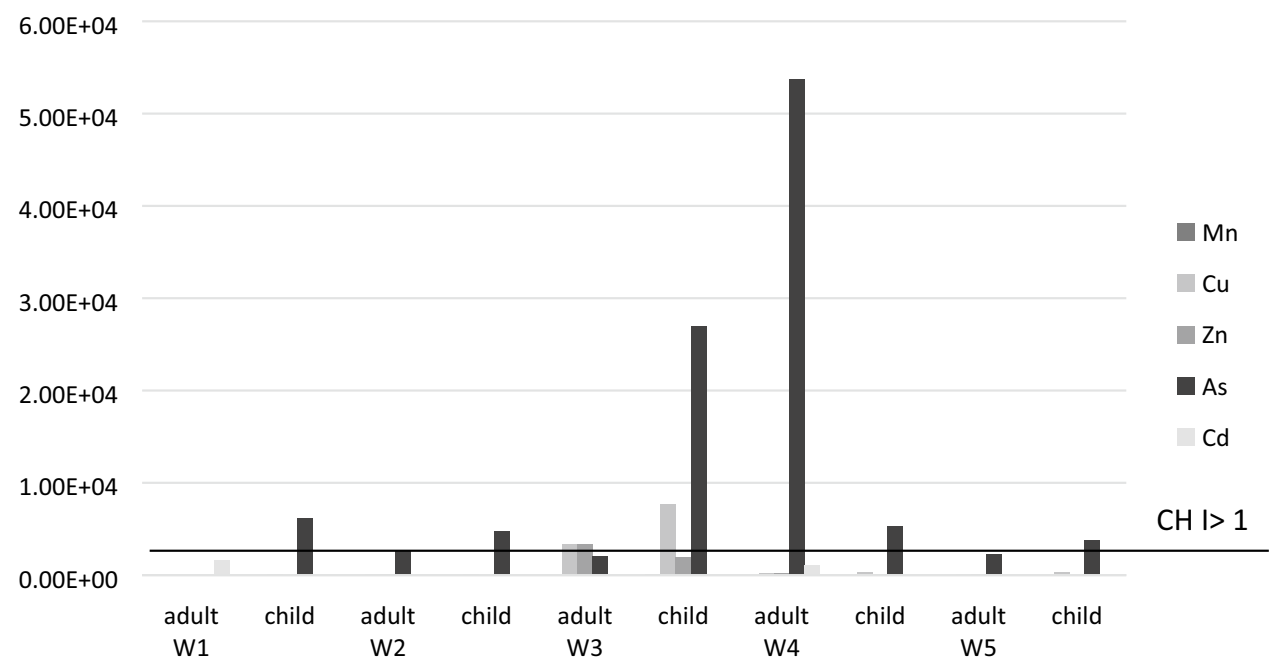

Arsenic cancer risk

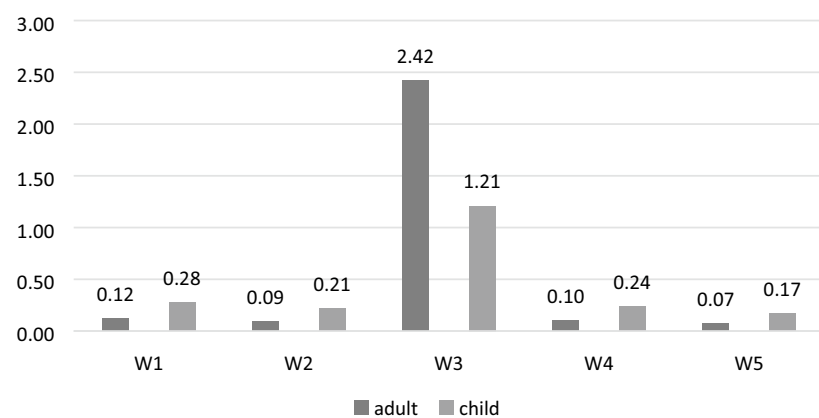

Fig. 5 Arsenic cancer risk

SN Applied Sciences non-acceptable by far compared to the risk limit. The results of this study are comparable to the results with $[1,10,11$, $15,22,40]$.

\section{Conclusions}

Water contaminated by high concentrations of heavy metals is currently a serious problem in many parts of the world. The reason behind this issue is the rapid social and economic development over the last few decades. Heavy metals naturally occur in water, but additional contributions come 
mainly from anthropogenic activities (agriculture, urbanization, industrialization, and mining).

The results of this study provide valuable information on the contamination of metals in Smolnik creek in terms of environmental and public health.

The analysis used herein involves the use of appropriate technical indicators of pollution to study the source of chemical parameters in water from 2006 to 2017, and the indicators were monitored in Smolnik creek at five sample sites. In terms of significance, W4 and W5 sampling sites were studied as sources of pollution and are located under the main source of pollution (Pech shaft).

The aim of this study was assessing the associated level of risk for adults and children through ingestion and dermal contact in Smolnik waters from heavy metals $(\mathrm{Mn}, \mathrm{Cu}, \mathrm{Zn}$, $A s$, and (d). On the basis of the daily intake values found in this study, every day, the heavy metal intake at all five sample sites was lower in adults than in children via both pathways of exposure. The inhalation exposure pathway was negligible because of the low release of heavy metals into the air. The non-carcinogenic risk values from heavy metals at the localities were lower in adults than in children. Values of $\mathrm{HQ}$ exceeded at least value in each sample site by both pathways. The non-carcinogenic risk associated with human exposure to heavy metal in water was therefore highest at sample site W3 and lowest at sample site W5. The results of the study indicate that there is a significant risk of heavy metal exposure at site W3 compared to those at the other four locations. The detailed assessment of the carcinogenic risks of different samples suggests that the carcinogenic risk factor for arsenic varies from site to site. An unacceptable risk threshold was found at all five sample sites, because the cancer risk values were higher than $1 \times 10^{-4}$.

The most important theory of the value and practical significance of health risk assessment lies in the acceleration of green extraction resources and the achievement of harmonization between the extractive industry, the environment, and human health.

Acknowledgements This work has been supported by the Slovak Grant Agency for Science (Grant No. 1/0419/19).

\section{Compliance with ethical standards}

Conflict of interest The authors declare that they have no conflict of interest.

\section{References}

1. Adamu Cl, Nganje TN, Edet A (2015) Heavy metal contamination and health risk assessment associated with abandoned barite mines in Cross River State, southeastern Nigeria. Environ Nanotechnol Monitor Manag 3:10-21
2. Ahmet $D$, Fevzi AL, Tuna AL, Nedim O (2006) Heavy metals in water, sediment and tissues of Leciscus cephalus from stream in southwestern Turkey. Chemosphere 63:1451-1458

3. Bai JH, Cui BS, Chen B, Zhang KJ, Deng W, Gao HF, Xiao R (2011) Spatial distribution and ecological risk assessment of heavy metals in surface sediments from a typical plateau lake wetland. China Ecol Modell 6:222-301. https://doi.org/10.1016/j.ecolm odel.2009.12.002

4. Balci N, Mayer B, Wayne CS, Mandernack K (2012) Oxygen and sulfur isotope systematics of sulfate produced during abiotic and bacterial oxidation of sphalerite and elemental sulfur. Geochim Cosmochim Acta 77:335-351

5. Balci N, Wayne CS, Mayer B, Mandernack K (2007) Oxygen and sulfur isotope systematics of sulfate by bacterial and abiotic oxidation of pyrite. Geochim Cosmochim Acta 71(15):3796-3811

6. Balintova M, Singovszka E, Vodička R, Purcz P (2016) Statistical evaluation of dependence between $\mathrm{pH}$, heavy metals concentration and flow rate in the Smolnik creek affected by acid mine drainage. Mine Water Environ 35(1):10-17

7. Bouzahzah $\mathrm{H}$, Benzaazoua $M$, Bussičre $B$ (2006) Acid-generating potential calculation using mineralogical static test: modification of the Paktunc equation. In: Proceedings of $23^{\text {rd }}$ World Mining Congress, Montreal, QC, Canada

8. Celik-Balcı N (2010) Effect of bacterial activity on trace metals release from oxidation of sphalerite at low $\mathrm{pH}(<3)$ and implications for AMD environment. Environ Earth Sci 60(3):485-493

9. Demkova L, Bobullská L, Arvay J, Jezny T, Ducsay L (2017) Biomonitoring of heavy metals contamination by mosses and lichens around Slovinky tailing pond (Slovakia). J Environ Sci Health 52(1):30-36. https://doi.org/10.1080/10934 529.2016.1221220

10. Frimpong SK, Koranteng SS (2019) Levels and human health risk assessment of heavy metals in surface soil of public parks in Southern Ghana. Environ Monit Assess 191(9)

11. Gevorgyan GA, Ghazaryan KA, Movsesyan HS, Zhamharyan HG (2017) Human health risk assessment of heavy metal pollution in soils around kapan mining area, Armenia. Electr J Nat Sci 2(29):29-33

12. Guideline No. 623/98-2 (1998)

13. Hakanson $L$ (1980) An ecological risk index for aquatic pollution control. A sedimentological approach. Water Res. 14:975-1001. https://doi.org/10.1016/0043-1354(80)90143-8

14. Hogstand C, Haux C (2011) Binding and detoxification of heavy metals in lower vertebrates with reference to metallothionein. Comp Biochem Physiol C 100:137-214. https://doi. org/10.1016/0742-8413(91)90140-O

15. Kifayatullah K et al (2013) Health risk associated with heavy metals in the drinking water of Swat, northern Pakistan. J Environ Sci 25(10):2003-2013

16. Krishna AK, Satyanarayanan M, Govil PK (2009) Assessment of heavy metal pollution in water using multivariate statistical techniques in an industrial area: a case study from Patancheru, Medak District, Andhra Pradesh India. J Hazard Mater 167:366-373

17. Lapakko KA (2002) Metal mine rock and waste characterization tools: an overview, mining, minerals and sustainable development. Report 67, 2002 Acid Drainage Technology Initiative. http://pubs.iied.org/pdfs/G00559.pdf

18. Lottermoser BG (2010) Mine wastes: characterization, treatment and environmental impacts, 3rd edn. Springer, Berlin

19. Luptáková A, Špaldon T, Bálintová M (2007) Remediation of acid mine drainage by means of biological and chemical methods. Adv Mater Res Biohydrometall Single Cell Environ 20-21:283-286

20. Methodical instruction $1 / 2012$ (legislation in Slovak republic for risk assessment) 
21. Muhammmad S, Shah MT, Khan S (2010) Arsenic health risk assessment in drinking water and source apportionment using multivariate statistical techniques in Kohistan region, northern Pakistan. Food Chem Toxicol 48:2855-2864

22. Ogbiye AS et al (2018) Human health risk assessment data of trace elements concentration in tap water-Abeokuta South, Nigeria. Data Brief 18:1416-1426

23. Ogunkunle CO, Fatoba PO, Ogunkunla OM, Oyedeji AA (2013) Potential Health Risk Assessment for soil Heavy metal Contaminant ion of Sagamu South-West Nigeria due to Cement Production. Int J Appl Sci Technol 3(2):89-96

24. Ouyang Y, Higman J, Thompson J, Toole OT, Campbell D (2002) Characterization and spatial distribution of heavy metals in sediment from Cedar and Ortega Rivers sub-basin. J Contam Hydrol 54:19-35

25. Pekey H, Karaka D, Bakoglu M (2004) Source apportionment of heavy metals in surface waters of a polluted stream using multivariate statistical analyses. Mar Pollut Bull 49:809-818

26. Qu C-S, Ma Z-W, Yang J, Liu Y, Bi J, Huang L (2012) Human Exposure Pathways of Heavy Metals in a Lead-Zinc Mining Area, Jiangsu Province, China. PLoS ONE 7(11):e46793

27. Rajeswari TR, Sailaja N (2014) Impact of heavy metals on environmental pollution. J Chem Pharm Sci 3:175-181

28. Sahoo PK, Tripathy S, Panigrahi MK (2014) Equeenuddin Sk-Md. Geochemical characterization of coal and waste rocks from a high sulfur bearing coalfield, India: implication for acid and metal generation. J Geochem Explor 145:135-147

29. Simeonov V, Stratis J, Samara C, Zachariadis G, Voutsa D, Anthemidis A, Sofoniou M, Kouimtzis T (2003) Assessment of the surface water quality in Northern Greece. Water Res 37:4119-4124

30. Singovszka E, Balintova M, Demcak S, Pavlikova P (2017) Metal pollution indices of bottom sediment and surface water affected by acid mine drainage. Metals $7(8): 1-11$
31. Singovszka E, Balintova M, Junakova N (2013) Evaluation of surface water pollution in the Smolnik creek. In: 13th international multidisciplinary scientific geoconference, SGEM 2013 vol 1, 445-450

32. Singovszka E, Balintova M, Junakova N (2016) The effect of sediment grain size on heavy metal content in different depth in water reservoir Ruzin, Slovakia. Solid State Phenom 244:240-245

33. Sutherland RA (2000) Bed sediment-associated trace metals in an urban stream, Oahu, Hawaii. Environ Geol 39(6):611-637

34. Tamasi G, Cini R (2004) Heavy metals in drinking waters from Mount Amiata. Possible risks from arsenic for public health in the province of Siena. Sci Total Environ 327:41-51

35. Teodorovic I, Djukic N, Maletin S, Miljanovic B, Jugovac N (2000) Metal pollution index: proposal for freshwater monitoring basedon trace metal accumulation in ish. Tiscia 32:55-60

36. Thomilson DC, Wilson JG, Harris CR, Jeffrey DW (1980) Problems in assessment of heavy metals in estuaries and the formation of pollution index. Helgol Meeresunlters 33:566-575

37. US EPA (2008) National Standards for Drinking Water Quality, Pakistan Environmental Protection Agency, (Ministry of Environment) Government of Pakistan

38. USEPA (2010) Risk Assessment Guidance for Superfund Volume I. Human Health Evaluation Manual (Part A). In: Agency USEP, editor. Washington, DC

39. WHO (2008) Guidelines for drinking water quality, 3rd Ed, Recommendations, vol 1. Geneva

40. Xiao J, Wang L, Deng L, Jin Z (2019) Characteristics, sources, water quality and health risk assessment of trace elements in river water and well water in the Chinese Loess Plateau. Sci Total Environ 650:2004-2012

Publisher's Note Springer Nature remains neutral with regard to jurisdictional claims in published maps and institutional affiliations. 